\title{
COMBINED CENTRAL DIABETES INSIPIDUS AND CEREBRAL SALT WASTING SYNDROME AFTER
}

\author{
HEMORRHAGIC STROKE-FIRST REPORT
}

\author{
Taraneh MAJIDI ${ }^{1}$, Elyar Sadeghi HOKMABADI ${ }^{2}$, Farhad MIRZAEI ${ }^{3}$, Ata MAHMOODPOOR ${ }^{4}$, Jalal \\ ETEMADI $^{1}$, Ali TAGHIZADIEH ${ }^{5}$, Bita RAHBARI ${ }^{6}$, Yalda SADEGHPOUR ${ }^{7}$, Elif SARIÖNDER GENÇER ${ }^{8}$
}

1Tabriz University of Medical Sciences, Kidney Research Center, Tabriz, IRAN

${ }^{2}$ Tabriz University of Medical Sciences, Emergency Medicine Research Team, Tabriz, IRAN

${ }^{3}$ Tabriz University of Medical Sciences, Faculty of Medicine, Department of Neurosurgery, Tabriz, IRAN

4Tabriz University of Medical Sciences, Faculty of Medicine, Department of Anesthesiology, Tabriz, IRAN

${ }^{5}$ Tabriz University of Medical Sciences, Tuberculosis and Lung Disease Research Center, Tabriz, IRAN

6Tabriz University of Medical Sciences, Connective Tissue Diseases Research Center, Tabriz, IRAN

${ }^{7}$ Tabriz University of Medical Sciences, Neurosciences Research Center, Tabriz, IRAN

8University of Health Sciences, Antalya Training and Research Hospital, Neurology Clinic, Antalya, TURKEY

\begin{abstract}
Disorders of water and electrolyte hemostasis such as diabetes insipidus (DI) and cerebral salt wasting syndrome (CSWS) have been described after cerebral insults, but combined DI and CSWS has rarely been reported in patients with traumatic intracranial hemorrhage (ICH). To the best of our knowledge this is the first report of combined DI and CSWS in an adult patient following hemorrhagic stroke: a previously healthy 40-year-old woman developed dysarthria and progressive decline in consciousness while lecturing. Cerebral computed tomography (CT) showed hyperdensity in the right basal ganglia, indicating ICH. Urgent digital subtraction angiography (DSA) was normal, external ventricular drainage (EVD) was placed and barbiturate coma was initiated. At the second day, she developed DI, which responded to desmopressin. From the 4th day, serum concentration of sodium started to decrease gradually, urine specific gravity increased, and massive polyuria that was unresponsive to desmopressin occurred. Based on test results, combined DI and CSWS was diagnosed and a triple treatment was initiated with high doses of hypertonic saline, desmopressin and a fludrocortisone. Water and electrolyte disturbances improved gradually and she was discharged after 28 days with a GOS-E of 7.

Keywords: Diabetes insipidus, cerebral salt wasting syndrome, spontaneous intracranial hemorrhage, brain hemorrhage.
\end{abstract}

\footnotetext{
Address for Correspondence: Assoc. Prof. Elyar Sadeghi Hokmabadi, MD. Imam Reza Hospital, Golgasht, Tabriz, Iran. Phone: +984133342889 E-mail: aeass@yahoo.com Received: $24.12 .2020 \quad$ Accepted: 09.03 .2021

ORCID IDs: Taraneh Majidi 0000-0002-1242-800X, Elyar Sadeghi Hokmabadi 0000-0002-5481-6027, Farhad Mirzaei 0000-0003-0560-3110, Ata Mahmoodpoor 0000-0002-4361-6230, Jalal Etemadi 0000-0001-8963-7494, Ali Taghizadieh 0000-0001-5779-5148, Bita Rahbari 0000-0001-5483-1166, Yalda Sadeghpour 0000-0003-4939-9895, Elif Sariönder Gençer 0000-0003-3881-9559.

Please cite this article in press as: Majidi T, Hokmabadi ES, Mirzaei F, Mahmoodpoor A, Etemadi J, Taghizadieh A, Rahbari B, Sadeghpor Y, Sarı̈nder Gençer E. Combined central diabetes insipidus and cerebral salt wasting syndrome after hemorrhagic stroke-first report. Turkish Journal of Cerebrovascular Diseases 2022; 28(3): 185-188. doi: 10.5505/tbdhd.2021.52386
} 
Majidi et al.

\section{HEMORAJIK İNME SONRASI KOMBINE SANTRAL DIYYABET İNSIPIDUS VE SEREBRAL TUZ KAYBI SENDROMU-ILK RAPOR}

öz

Beyin hasarı sonrası diyabet insipidus (DI) ve serebral tuz kaybı sendromu (STKS) gibi su ve elektrolit hemostaz bozuklukları tanımlanmıştır, ancak kombine DI ve STKS travmatik intrakraniyal kanamalı (IKK) hastalarda nadiren bildirilmiştir. Bildiğimiz kadarıyla yazımız yetişkin bir hastada hemorajik inmeyi takiben gelișen kombine Dİ ve STKS'nin ilk raporudur: 40 yaşında sağlıklı bir kadın ders anlatırken ani dizartri ve giderek artan bilinç kaybı gelişmiştir. bilgisayarlı beyin tomografsinde (BBT) sağ bazal gangliyonda intraserebral kanama (ISK) ile uyumlu hiperdens lezyon gösterildi. Acil yapılan digital subtraction anjografisi (DSA) normaldi, eksternal ventriküler drenaj (EVD) yerleştirildi ve barbitürat koma başlandı. İkinci gün desmopressine yanıt veren Dİ gelişti. 4. günden itibaren serum sodyum konsantrasyonu yavaş yavaş azalmaya başladı, idrar dansitesi arttı ve desmopressine yanıt vermeyen masif poliüri oluştu. Test sonuçlarına göre, kombine DI ve STKS tanısı konulan hastaya yüksek dozlarda hipertonik salin, desmopressin ve fludrokortizon ile üçlü tedavi başlatıldı. Su ve elektrolit bozuklukları kademeli olarak düzeldi ve 28 gün sonra Glasgow Outcome Scale-Extended (GOS-E) 7 ile taburcu edildi.

Anahtar Sözcükler: Diabetes insipidus, serebral tuz kaybı sendromu, spontan intraserebral kanama, beyin kanaması.

\section{INTRODUCTION}

Disorders of water and electrolyte hemostasis such diabetes insipidus (DI) and cerebral salt wasting syndrome (CSWS) have been described after traumatic brain injury, neoplasia, infection, and ischemic stroke $(1,2)$, but combined DI and CSWS has rarely been reported in literature in patients with traumatic intra cranial Hemorrhage (ICH) (3). To the best of our knowledge, this is the first report of combined DI and CSWS in an adult patient after hemorrhagic stroke.

\section{CASE REPORT}

While lecturing at work, a previously healthy 40-year-old woman suddenly developed dysarthria and vomiting followed by progressive decline in consciousness. Initial level of consciousness was stupor; a detailed examination revealed left hemiparesis and asymmetrical plantar reflex. Intubation was performed. Cerebral computed tomography (CT) showed hyperdensity in right basal ganglia indicating intracranial hemorrhage (ICH) associated with intraventricular hemorrhage (IVH) in the lateral and 3rd ventricles accompanied by a midline shift about $3 \mathrm{~mm}$ (Figure 1). Urgent digital subtraction angiography (DSA) was done which was normal. External ventricular drainage (EVD) was placed into the left lateral ventricle and she was admitted to stroke care unit (SCU). After surgery she was placed under mechanical ventilation, barbiturate coma was initiated and hyperthermia was treated aggressively. She had no previous history of known illness or drug use, and laboratuary data were normal at the initial evaluation.

On the second day following admission, she had a significant increase in urine volume of about $6000 \mathrm{ml}$ over 24 hours with urine specific gravity of 1.005 (urine osmolality was not measured) and a plasma sodium concentration of $149 \mathrm{mmol} / \mathrm{L}$, blood urea nitrogen of $56 \mathrm{mg} / \mathrm{dl}$, and blood glucose of $140 \mathrm{mg} / \mathrm{dl}$; thus, serum osmolality was estimated at $326 \mathrm{mosm} / \mathrm{kg}$. Based on the above results and since she was not on any diuretic, diabetes insipidus (DI) was suspected and treatment with desmopressin was initiated. Fluid replacement was provided to correct volume depletion. Her urine flow rate declined, which was the expected response to desmopressin.

On the fourth day, the serum concentration of sodium started to decrease gradually. On the fifth day, Sodium ( $\mathrm{Na}$ ) concentration was $136 \mathrm{mmol} / \mathrm{L}$, urine specific gravity was 1.020 , and polyuria was resistant to desmopressin. Massive polyuria (urine volume of more than $10 \mathrm{~L} /$ day) developed and hyponatremia became progressively more severe. On the sixth day, urine spot analysis showed that urine $\mathrm{Na}$ concentration was $250 \mathrm{mEq} / \mathrm{L}$ with a serum Na concentration of $132 \mathrm{mEq} / \mathrm{L}$. The patient was hypovolemic with central vein pressure (CVP) of 4-5 $\mathrm{cm} \mathrm{H}_{2} \mathrm{O}$. At this time the patient was not on mannitol or other diuretics. Serum pro-BNP level was tested on day 15 and was within normal limits. To avoid a further decline in $\mathrm{Na}$ concentration, which also worsens brain cell swelling, a hypertonic sodium chloride $(\mathrm{NaCl}) 5 \%$ infusion was started with the goal of a serum $\mathrm{Na}$ concentration of $145-150 \mathrm{mmol} / \mathrm{L}$. Since the 


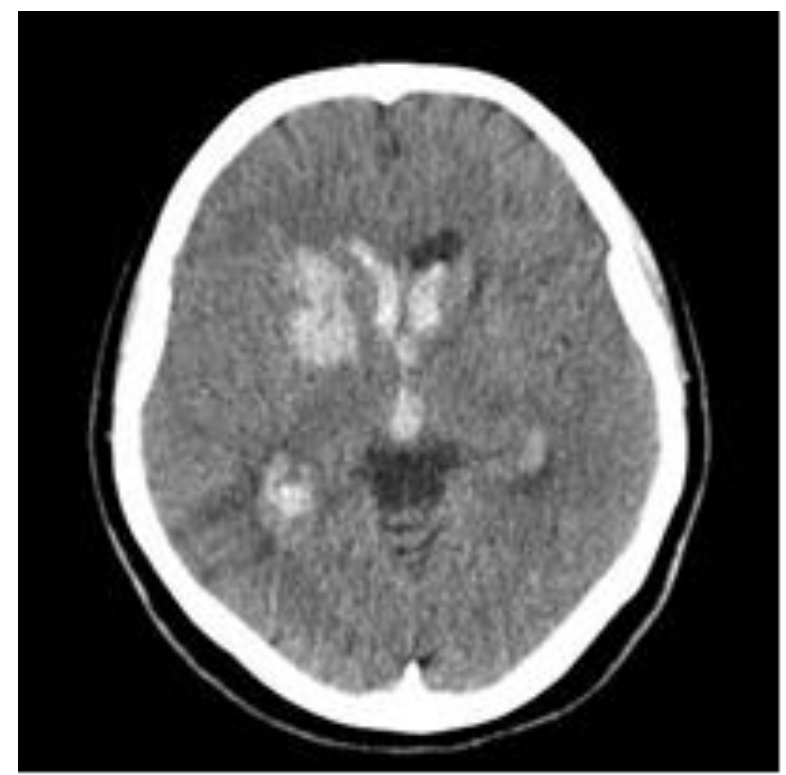

Figure 1. Cerebral computed tomography (CT) showing hyperdensity in right basal ganglia indicating intracranial hemorrhage $(\mathrm{ICH})$ associated with intraventricular hemorrhage (IVH).

hyponatremia was very resistant to treatment despite hypertonic saline replacement, the desmopressin was suspended. Fluid replacement with isotonic serum equal to urine output was continued. Based on patient's history (hemorrhagic stroke), massive polyuria (more than $10 \mathrm{~L} /$ day) resistant to desmopressin, high normal urine specific gravity (1.030), high urine $\mathrm{Na}$ excretion and decreasing serum $\mathrm{Na}$ concentration, we speculated that salt wasting syndrome (SWS) was added to DI. Maximum 24h urine volume was about $16 \mathrm{~L} /$ day on the 9 th day and the maximum hypertonic $\mathrm{NaCl} 5 \%$ infusion rate needed to maintain serum $\mathrm{Na}$ concentration at a high normal level was $80 \mathrm{cc} / \mathrm{h}$ (equal to 133 $\mathrm{ml} / \mathrm{h}$ of $\mathrm{NaCl} 3 \%)$. On the $11^{\text {th }}$ day, since the serum $\mathrm{Na}$ concentration was stable in the normal range, desmopressin was restarted for better control of polyuria.

Based on the previous case studies, treatment for combined DI and CSWS (triple therapy) was continued using hypertonic saline, desmopressin and fludrocortisone (0.1 mg every 12 hours). Urine volume decreased significantly to less than $10 \mathrm{~L} / \mathrm{d}$.

Control brain computed tomography (CT) scans were done at regular intervals with no evidence of hydrocephalus. The barbiturate coma was continued for 5 days. On the $14^{\text {th }}$ day, the patient started to awaken gradually and was extubated on the $18^{\text {th }}$ day. External ventricular drainage (EVD) was withdrawn on the $19^{\text {th }}$ day.

Desmopressin, hypertonic saline infusion and fludrocortisone continued until $20^{\text {th }}, 25^{\text {th }}$ and $28^{\text {th }}$ (discharge day), respectively. Before discharge a brain MRI was conducted to rule out cavernous angioma as a cause of cerebral hemorrhage and pontine demyelination, with normal results. On the $28^{\text {th }}$ day the patient was discharged with slight weakness of the right hand with a modified Rankin Scale of 2 and Glasgow outcome Scale-Extended (GOS-E) of 7. Informed consent was obtained from the patient for this report.

\section{DISCUSSION AND CONCLUSION}

Combined diabetes insipidus (DI) and cerebral salt wasting syndrome (CSWS) has rarely been reported in neurological disease (3). In this syndrome, DI generally comes before CSWS (3). DI presents first with polyuria, hypotonic urine, and hypernatremia, and responds to desmopressin. CSWS presents later, and the combined syndrome of DI and CSWS should be suspected if: 1) massive polyuria (over $10 \mathrm{~L} /$ day, rare in patients with DI or CSWS alone) with no response to desmopressin alone; 2) high $24 \mathrm{~h}$ urine $\mathrm{Na}$ excretion with normal serum Na concentration (DI increases / CSWS decreases serum Na concentration); 3) normal urine specific gravity (DI decreases / CSWS increases urine specific gravity); and 4) high urine osmolarity (more than serum osmolarity).

It is very important to note that the short transition time from DI to combined syndrome must be correctly and quickly recognized by the attending physician. In such patients, an increase in urine volume may erroneously be interpreted as inadequate treatment with vasopressin and may results in dose increment; since continuing desmopressin without replacing $\mathrm{Na}$ loss is a "fatal error". Because this patient had both a very large amount of urine volume and a very high urine $\mathrm{Na}$ excretion, infusion of high amounts of hypertonic saline was required to prevent a severe and lethal degree of hyponatremia. Thus infusion of a hypotonic solution is contraindicated in such patients. In a similar patient with combined syndrome reported by Laredo, a 42-year-old previously healthy female with subarachnoid hemorrhage had a sudden decrease in serum $\mathrm{Na}$ concentration from $155 \mathrm{mmol} / \mathrm{l}$ to $123 \mathrm{mmol} / \mathrm{l}$ over a period of $24 \mathrm{~h}$, resulting in death (4). Recognition of the short transition time from DI to 
combined syndrome is crucial and a very high rate of mortality and morbidity has been reported without proper treatment (5).

Our case also showed that in patients with combined syndrome how extreme urine $\mathrm{Na}$ loss can be, and that it can also safely be replaced with very large amounts of hypertonic saline.

Another point worth noting is that vasopressin was able to be discontinued earlier than hypertonic $\mathrm{NaCl}$ infusion and fludrocortisone in this case. Unlike cases reported by $\mathrm{Wu}$ (3), it seems that CSWS lasted longer than DI in this patient.

To best of our knowledge this is the first report of combined diabetes Insipidus (DI) and cerebral salt wasting syndrome (CSWS) in an adult patient after spontaneous intra cranial hemorrhage (ICH). Recognition of the short transition time from DI to combined syndrome is crucial. Once diagnosed, triple treatment with hypertonic saline, desmopressin and a mineralocorticoid should be started to balance fluid volume and Na concentration. A very large amount of Na replacement may be needed. Most physicians are unaware of the incidence of this combined syndrome which may be a reason for under reporting and high mortality of such patients.

\section{REFERENCES}

1. Costa M, Esteves C, Castedo JL, et al. A challenging coexistence of central diabetes insipidus and cerebral salt wasting syndrome: A case report. Journal of Medical Case Reports 2018; 12(1): 212.

2. Tisdall, M, Crocker M, Watkiss J, et al. Disturbances of sodium in critically ill adult neurologic patients: A clinical review. Journal of Neurosurgical Anesthesiology 2006; 18(1): 57-63.

3. Wu, X., et al., Diagnosis and Management of Combined Central Diabetes Insipidus and Cerebral Salt Wasting Syndrome After Traumatic Brain Injury. World Neurosurgery 2016; 88: 483-487.

4. Laredo, S, Yuen K, Sonnenberg B, et al. Coexistence of central diabetes insipidus and salt wasting: The difficulties in diagnosis, changes in natremia, and treatment. J Am Soc Nephrol 1996; 7(12): 2527-2532.

5. Lin JJ, Lin KL, Hsia SH, et al. Combined central diabetes insipidus and cerebral salt wasting syndrome in children. Pediatric Neurology 2009; 40(2): 84-87.

\section{Ethics}

Informed Consent: The authors declared that informed consent form was signed by the patient.

Copyright Transfer Form: Copyright Transfer Form was signed by the authors.

Peer-review: Internally peer-reviewed.

Authorship Contributions: Surgical and Medical Practices: TM, ESH, FM, AM, JE, AT, BB, YS, ESG. Concept: TM, ESH, FM, AM, JE, AT, BB, YS, ESG. Design: TM, ESH, FM, AM, JE, AT, BB, YS, ESG. Data Collection or Processing: TM, ESH, FM, AM, JE, AT, BB, YS, ESG. Analysis or Interpretation: TM, ESH, FM, AM, JE, AT, BB, YS, ESG. Literature Search: TM, ESH, FM, AM, JE, AT, BB, YS, ESG. Writing: TM, ESH, FM, AM, JE, AT, BB, YS, ESG.

Conflict of Interest: No conflict of interest was declared by the authors.

Financial Disclosure: The authors declared that this study received no financial support. 